\title{
Cultural Influence and Commitment to Teacher Professionalism
}

\author{
Rusmeini Ningsih ${ }^{1 *}$, Bukman Lian², Mulyadi ${ }^{2}$ \\ ${ }^{I}$ SD Negeri 14 Kayuagung, Palembang, Indonesia \\ ${ }^{2}$ Universitas PGRI Palembang, Indonesia \\ *Corresponding author. Email: rusmeini21@gmail.com
}

\begin{abstract}
This study aims to determine the effect of work culture and work commitment on teacher professionalism. This research was conducted at SD Negeri Kayuagung District, Ogan Komering Ilir Regency, Indonesia. The sample of this study was 60 people. The research method uses quantitative. The data collection technique is a questionnaire. The data analysis technique used the normality test, linearity test and test. The results of the study concluded that there was a significant influence between work culture and work commitment to teacher professionalism.
\end{abstract}

Keywords: Work Culture, Work Commitment, Teacher Professionalism

\section{INTRODUCTION}

Improving the quality of national education can be done if all the tools are functioning properly, the teacher is one of the educational tools. Based on the results of several research studies on teacher quality have an effect on the success of students in transforming science and technology and internalizing ethics and morals. The quality of teachers has an effect of $34 \%$, the principal is $22 \%$, the facilities and infrastructure are $26 \%$, and the learning time is $18 \%$ [1]. Based on these data, it is natural that when discussing education, the teacher is the first to be discussed, the role of the teacher in the teaching and learning process becomes the spearhead and even determines the success or failure of education.

A good work culture in an organization / institution will achieve maximum performance. A good work culture can provide benefits, including: (1) maintaining a harmonious and harmonious work environment; (2) create an orderly work atmosphere; (3) make the work atmosphere orderly and safe, (4) determine the implementation of work rights and obligations; (5) welfare and welfare of workers; and (6) increasing high morale and easy to adapt to circumstances [2].

Work commitment is a variable that reflects the degree of relationship that individuals perceive to have with certain jobs in the organization. Greenberg and Baron [3] suggest that work commitment reflects the level of identification and involvement of individuals in their work and their unwillingness to leave the job.

The attitude of professionalism in the world of education is not only considered a formality but must be functional and become the basic principle that underlies its operational actions. A good teacher is those who meet the requirements of professional ability as an educator. In other words, to improve the quality of education, professional teachers are required. It is an obligation for an educational institution, that the development of teacher professionalism is a big responsibility that cannot be postponed anymore. Because, delaying this means sacrificing future generations, which incidentally is the reserve of civilization for the people.

In this regard, many factors cause low professionalism, among others, there are still many teachers who do not fully pursue their profession and a lack of teacher motivation to improve their quality. Apart from the above factors, the cause of low teacher professionalism can be caused by a weak work culture. Work culture is part of school culture.

Based on initial observations, researchers found actions related to work culture and teacher work commitment. The researcher observes each of these actions, so that the researcher can illustrate that there is a good work culture but has not fulfilled the desired regulations, such as teachers who come late to school, young teachers who make special groups at school, some teachers who teach less. effective, even though the regulations have been committed in the school, but it has not been going well. Some teachers are reluctant to be actively involved in activities at school, they do not care about preparing lesson plans, do not know the vision and mission of the school. In fact, the vision and mission are values and goals that are understood and accepted by a series of efforts and activities.

\section{METHODS \\ This study uses explanatory research. Explanatory research is a type of research in which the}


researcher explains the causal relationship between variables through hypothesis testing, which is testing hypotheses based on previously formulated theories and then the data that has been obtained is calculated through a quantitative approach. Causal research examines the causal relationship between two or more variables [3], [4]. Causal research explains the effect of changes in value variations in one variable on changes in the value variations of other variables [6], [7].

This research was conducted at SD Negeri Kayuagung District, Ogan Komering Ilir Regency, Indonesia. This research was conducted from October to December 2020. The sample of this study was 60 people, taken from 108 teachers, in three schools (SD 14 Kayuagung, SD 15 Kayuagung, and SD 8 Kayuagung). Data collection was done by using a questionnaire technique. Data collection techniques are carried out by providing a set of questions and written statements to respondents to answer [7]. In this study, the questionnaire used was a choice type questionnaire by giving a checklist according to the answers given directly to the respondents. This was done with the consideration of limiting the answers from respondents so as not to deviate from the questionnaire discussion.

The questionnaire contains statements related to research variables that will be distributed to respondents according to the predetermined sample. This study used three questionnaires, namely: (1) to determine the work culture of teachers, with 12 indicators and 31 questions; (2) to determine teacher work commitment, there are 3 indicators with 25 questions; and (3) to determine teacher professionalism, there are 3 indicators and 25 questions.

The data analysis technique used is descriptive statistical techniques and simple regression. Descriptive statistical analysis in this study is to describe the data with a frequency distribution, histogram, measurement of the mean (mean), mode, median, and standard deviation center values [8]. Data analysis using the help of the IBM SPSS Statistics 26.0 program. This calculation uses the formula:

$Y=a+b X$

Information:

$\mathrm{Y}=$ Dependent variable

$\mathrm{X}=$ Independent variable

a $=$ Constant value

$\mathrm{b} \quad=$ Regression direction coefficient [9]

Correlation analysis is used to determine the closeness of the relationship between variables. In this study, correlation analysis is used to determine the closeness of the relationship between teacher work culture $(\mathrm{X})$ and teacher professionalism $(\mathrm{Y})$ using the formula from Pearson, namely Product Moment correlation:
Information:

rxy $=$ The correlation coefficient between variables $\mathrm{X}$ and $\mathrm{Y}$

$\mathrm{N}=$ Number of samples

$\sum \mathrm{X}=$ Total score of variable $\mathrm{X}$

$\sum \mathrm{Y}=$ Total score of variable $\mathrm{Y}$

\section{RESULTS AND DISCUSSION}

\subsection{Description Data}

As for data Work culture is presented in Table 1. Based on Table 1, the frequency distribution is known that $33 \%$ of respondents answered high and $66 \%$ of respondents answered very high. Table 2 presents the results of the analysis of work culture data descriptions. Based on Table 2, it is known that the average $=91.60$ and standard deviation $=4.578$. Based on these data, it is known that work culture is included in the very high category. Figure 1 presents the frequency distribution of work culture.

Table 1 Work Culture Data Variables

\begin{tabular}{|c|c|c|c|c|c|c|c|c|c|c|}
\hline \multicolumn{10}{|c|}{ Table 1 Work Culture Data Variables } \\
\hline \multicolumn{10}{|c|}{ Respondents' } & \multicolumn{7}{|c|}{ WORK CULTURE } & \multicolumn{3}{|c|}{ Percentage } & $\%$ \\
\hline Item & $\mathbf{1}$ & $\mathbf{2}$ & $\mathbf{3}$ & $\mathbf{4}$ & & $\mathbf{1}$ & $\mathbf{2}$ & $\mathbf{3}$ & $\mathbf{4}$ & \\
\hline & SR & R & T & ST & & SR & R & R & ST & \\
\hline 1 & 0 & 0 & 6 & 54 & 60 & 0 & 0 & 10 & 90 & 100 \\
\hline 2 & 0 & 0 & 16 & 44 & 60 & 0 & 0 & 27 & 73 & 100 \\
\hline 3 & 0 & 0 & 16 & 44 & 60 & 0 & 0 & 27 & 73 & 100 \\
\hline 4 & 0 & 0 & 12 & 48 & 60 & 0 & 0 & 20 & 80 & 100 \\
\hline 5 & 0 & 0 & 20 & 40 & 60 & 0 & 0 & 33 & 67 & 100 \\
\hline 6 & 0 & 0 & 14 & 46 & 60 & 0 & 0 & 23 & 77 & 100 \\
\hline 7 & 0 & 0 & 16 & 44 & 60 & 0 & 0 & 27 & 73 & 100 \\
\hline 8 & 0 & 0 & 37 & 23 & 60 & 0 & 0 & 62 & 38 & 100 \\
\hline 9 & 0 & 0 & 17 & 43 & 60 & 0 & 0 & 28 & 72 & 100 \\
\hline 10 & 0 & 0 & 23 & 37 & 60 & 0 & 0 & 38 & 62 & 100 \\
\hline 11 & 0 & 0 & 19 & 41 & 60 & 0 & 0 & 32 & 68 & 100 \\
\hline 12 & 0 & 0 & 12 & 48 & 60 & 0 & 0 & 20 & 80 & 100 \\
\hline 13 & 0 & 0 & 25 & 35 & 60 & 0 & 0 & 42 & 58 & 100 \\
\hline 14 & 0 & 0 & 25 & 35 & 60 & 0 & 0 & 42 & 58 & 100 \\
\hline 15 & 0 & 0 & 15 & 45 & 60 & 0 & 0 & 25 & 75 & 100 \\
\hline 16 & 0 & 0 & 14 & 46 & 60 & 0 & 0 & 23 & 77 & 100 \\
\hline 17 & 0 & 0 & 22 & 38 & 60 & 0 & 0 & 37 & 63 & 100 \\
\hline 18 & 0 & 0 & 22 & 38 & 60 & 0 & 0 & 37 & 63 & 100 \\
\hline 19 & 0 & 0 & 19 & 41 & 60 & 0 & 0 & 32 & 68 & 100 \\
\hline 20 & 0 & 0 & 19 & 41 & 60 & 0 & 0 & 32 & 68 & 100 \\
\hline 21 & 0 & 0 & 16 & 44 & 60 & 0 & 0 & 27 & 73 & 100 \\
\hline 22 & 0 & 0 & 26 & 34 & 60 & 0 & 0 & 43 & 57 & 100 \\
\hline 23 & 0 & 1 & 26 & 33 & 60 & 0 & 2 & 43 & 55 & 100 \\
\hline 24 & 0 & 0 & 39 & 21 & 60 & 0 & 0 & 65 & 35 & 100 \\
\hline 25 & 0 & 0 & 26 & 34 & 60 & 0 & 0 & 43 & 57 & 100 \\
\hline Total & 0 & 1 & 502 & 997 & 1500 & 0 & 2 & 837 & 1662 & 2500 \\
\hline $\mathrm{X}$ & 0 & 0 & 20 & 40 & 60 & 0 & 0 & 33 & 66 & 100 \\
\hline & & & & & & \\
\hline
\end{tabular}

$\operatorname{rxy}=\frac{N \Sigma \mathrm{XY}-(\Sigma \mathrm{X})(\Sigma \mathrm{Y})}{\sqrt{\left(N \Sigma \mathrm{X}^{2}-(\Sigma \mathrm{X})^{2}\right)\left(N \Sigma \mathrm{Y}^{2}-(\Sigma \mathrm{Y})^{2}\right)}}$ 
Table 2 Descriptive Analysis of Work Culture Variables

\begin{tabular}{|c|c|c|}
\hline \multicolumn{3}{|c|}{ Statistics } \\
\hline Total X1 & & \\
\hline $\mathrm{N}$ & Valid & 60 \\
\hline Mean & Missing & 0 \\
\hline Std. Error of Mean & & 91.60 \\
\hline Median & & 0.591 \\
\hline Mode & & 92.00 \\
\hline Std. Deviation & & 94 \\
\hline Variance & & 4,578 \\
\hline Range & & 20,956 \\
\hline Minimum & & 24 \\
\hline Maximum & & 76 \\
\hline Sum & & 5496 \\
\hline
\end{tabular}

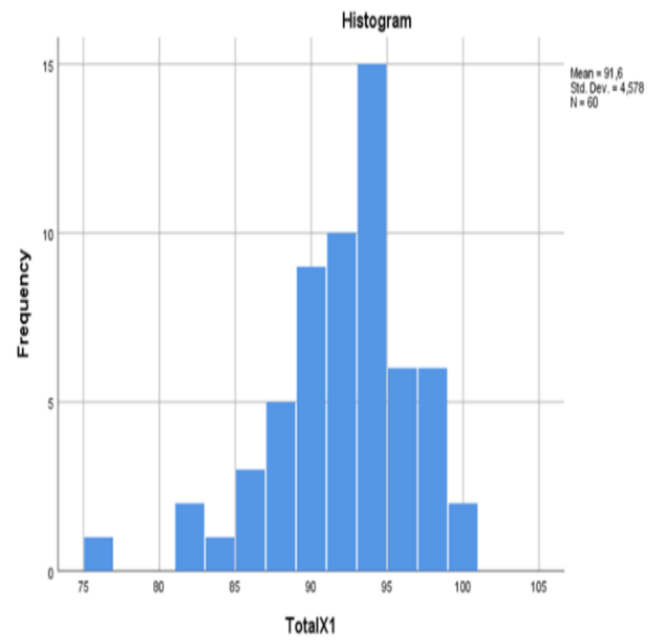

Figure 1 Distribution of Work Culture Variables

As for data Work commitment is presented in Table 3. Based on Table 3, it is known that an average of $34 \%$ of respondents answered high and $66 \%$ of respondents answered very high. Based on these data, it is known that work commitment is in the very high category. Table 4 presents the results of the descriptive analysis of work commitment data. Based on Table 4, it is known that the average $=90.12$ and the standard deviation $=4.499$. Figure 2 presents the frequency distribution of work commitments

As for data Professionalism is presented in Table 5. Based on Table 5, it is known that an average of $33.5 \%$ of respondents answered high and $66.4 \%$ of respondents answered very high. Based on these data, it is known that professionalism is in the very high category. Table 4 presents the results of the descriptive analysis of professionalism data. Based on Table 6 , it is known that the average $=$ 88.30 and standard deviation $=4.873$. Figure 2 presents the frequency distribution of work commitments.
Table 3 Data on Work Commitment Variables

\begin{tabular}{|c|c|c|c|c|c|c|c|c|c|c|}
\hline \multicolumn{11}{|c|}{ WORK COMMITMENT } \\
\hline \multicolumn{5}{|c|}{ Respondents' Answers } & & \multicolumn{4}{|c|}{ Percentage } & $\%$ \\
\hline Item & 1 & 2 & 3 & 4 & & 1 & 2 & 3 & 4 & \\
\hline & $\begin{array}{l}\mathrm{S} \\
\mathrm{R}\end{array}$ & $\mathrm{R}$ & $\mathrm{T}$ & ST & & $\begin{array}{l}S \\
R\end{array}$ & $\mathrm{R}$ & $\mathrm{R}$ & ST & \\
\hline 1 & 0 & 0 & 21 & 39 & 60 & 0 & 0 & 10 & 90 & 100 \\
\hline 2 & 0 & 0 & 28 & 32 & 60 & 0 & 0 & 27 & 73 & 100 \\
\hline 3 & 0 & 0 & 23 & 37 & 60 & 0 & 0 & 27 & 73 & 100 \\
\hline 4 & 0 & 0 & 19 & 41 & 60 & 0 & 0 & 20 & 80 & 100 \\
\hline 5 & 0 & 0 & 27 & 33 & 60 & 0 & 0 & 33 & 67 & 100 \\
\hline 6 & 0 & 0 & 20 & 40 & 60 & 0 & 0 & 23 & 77 & 100 \\
\hline 7 & 0 & 0 & 19 & 41 & 60 & 0 & 0 & 27 & 73 & 100 \\
\hline 8 & 0 & 0 & 29 & 31 & 60 & 0 & 0 & 62 & 38 & 100 \\
\hline 9 & 0 & 0 & 21 & 39 & 60 & 0 & 0 & 28 & 72 & 100 \\
\hline 10 & 0 & 0 & 25 & 35 & 60 & 0 & 0 & 38 & 62 & 100 \\
\hline 11 & 0 & 0 & 26 & 34 & 60 & 0 & 0 & 32 & 68 & 100 \\
\hline 12 & 0 & 0 & 19 & 41 & 60 & 0 & $\overline{0}$ & 20 & 80 & 100 \\
\hline 13 & 0 & 0 & 26 & 34 & 60 & 0 & 0 & 42 & 58 & 100 \\
\hline 14 & 0 & 0 & 27 & 33 & 60 & 0 & 0 & 42 & 58 & 100 \\
\hline 15 & 0 & 0 & 22 & 38 & 60 & 0 & 0 & 25 & 75 & 100 \\
\hline 16 & 0 & 0 & 22 & 38 & 60 & 0 & 0 & 23 & 77 & 100 \\
\hline 17 & 0 & 0 & 24 & 36 & 60 & 0 & 0 & 37 & 63 & 100 \\
\hline 18 & 0 & 0 & 23 & 37 & 60 & 0 & 0 & 37 & 63 & 100 \\
\hline 19 & 0 & 0 & 24 & 36 & 60 & 0 & $\overline{0}$ & 32 & 68 & 100 \\
\hline 20 & 0 & 0 & 27 & 33 & 60 & 0 & 0 & 32 & 68 & 100 \\
\hline 21 & 0 & 0 & 21 & 39 & 60 & 0 & 0 & 27 & 73 & 100 \\
\hline 22 & 0 & 0 & 26 & 34 & 60 & 0 & 0 & 43 & 57 & 100 \\
\hline 23 & 0 & 0 & 27 & 33 & 60 & 0 & 2 & 43 & 55 & 100 \\
\hline 24 & 0 & 0 & 28 & 32 & 60 & 0 & $\overline{0}$ & 65 & 35 & 100 \\
\hline 25 & 0 & 0 & 19 & 41 & 60 & 0 & 0 & 43 & 57 & 100 \\
\hline Total & 0 & 0 & 59 & $\begin{array}{c}90 \\
7\end{array}$ & $\begin{array}{c}150 \\
0\end{array}$ & 0 & 2 & $\begin{array}{c}83 \\
8\end{array}$ & $\begin{array}{c}166 \\
0\end{array}$ & $\begin{array}{c}250 \\
0\end{array}$ \\
\hline $\begin{array}{c}\text { Avera } \\
\text { ge }\end{array}$ & 0 & 0 & 24 & 36 & 60 & 0 & 0 & 34 & 66 & 100 \\
\hline
\end{tabular}

Table 4 Descriptive Analysis of Work Commitment Variables

\begin{tabular}{|l|l|r|}
\hline Statistics & & \\
\hline Total X2 & & \\
\hline N & Valid & 60 \\
\hline & Missing & 0 \\
\hline Mean & & 90.12 \\
\hline Std. Error of Mean & & 0.581 \\
\hline Median & & 90 \\
\hline Mode & 88 \\
\hline Std. Deviation & & 4,499 \\
\hline Variance & & 20.24 \\
\hline Range & & 24 \\
\hline Minimum & & 75 \\
\hline Maximum & & 99 \\
\hline Sum & 5407 \\
\hline
\end{tabular}

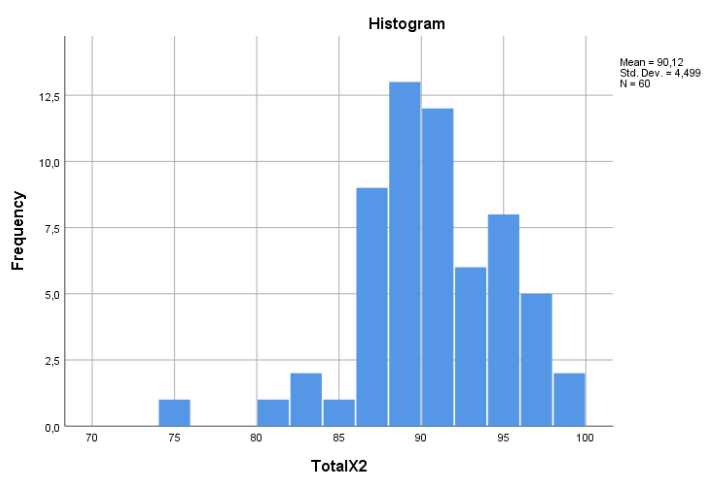

Figure 2 Distribution of Work Commitment Variables 
Table 5 Data on Professionalism Variable PROFESSIONALISM

\begin{tabular}{|c|c|c|c|c|c|c|c|c|c|c|}
\hline \multicolumn{11}{|c|}{ PROFESSIONALISM } \\
\hline \multicolumn{5}{|c|}{ Respondents' Answers } & & \multicolumn{4}{|c|}{ Percentage } & $\%$ \\
\hline Item & 1 & 2 & 3 & 4 & & 1 & 2 & 3 & 4 & \\
\hline & $\begin{array}{l}\mathrm{S} \\
\mathrm{R} \\
\end{array}$ & $\mathrm{R}$ & $\mathrm{T}$ & ST & & $\begin{array}{l}\mathrm{S} \\
\mathrm{R}\end{array}$ & $\mathrm{R}$ & $\mathrm{R}$ & ST & \\
\hline 1 & 0 & 0 & 33 & 27 & 60 & 0 & 0 & 10 & 90 & 100 \\
\hline 2 & 0 & 0 & 35 & 25 & 60 & 0 & 0 & 27 & 73 & 100 \\
\hline 3 & 0 & 0 & 27 & 33 & 60 & 0 & 0 & 27 & 73 & 100 \\
\hline 4 & 0 & 0 & 24 & 36 & 60 & 0 & 0 & 20 & 80 & 100 \\
\hline 5 & 0 & 1 & 27 & 32 & 60 & 0 & 0 & 33 & 67 & 100 \\
\hline 6 & 0 & 0 & 25 & 35 & 60 & 0 & 0 & 23 & 77 & 100 \\
\hline 7 & 0 & 0 & 33 & 27 & 60 & 0 & 0 & 27 & 73 & 100 \\
\hline 8 & 0 & 0 & 23 & 37 & 60 & 0 & 0 & 62 & 38 & 100 \\
\hline 9 & 0 & 0 & 19 & 41 & 60 & 0 & 0 & 28 & 72 & 100 \\
\hline 10 & 0 & 0 & 35 & 25 & 60 & 0 & 0 & 38 & 62 & 100 \\
\hline 11 & 0 & 0 & 33 & 27 & 60 & 0 & 0 & 32 & 68 & 100 \\
\hline 12 & 0 & 0 & 31 & 29 & 60 & 0 & 0 & 20 & 80 & 100 \\
\hline 13 & 0 & 0 & 28 & 32 & 60 & 0 & 0 & 42 & 58 & 100 \\
\hline 14 & 0 & 0 & 28 & 32 & 60 & 0 & 0 & 42 & 58 & 100 \\
\hline 15 & 0 & 0 & 28 & 32 & 60 & 0 & 0 & 25 & 75 & 100 \\
\hline 16 & 0 & 0 & 23 & 37 & 60 & 0 & 0 & 23 & 77 & 100 \\
\hline 17 & 0 & 0 & 32 & 28 & 60 & 0 & 0 & 37 & 63 & 100 \\
\hline 18 & 0 & 0 & 31 & 29 & 60 & 0 & 0 & 37 & 63 & 100 \\
\hline 19 & 0 & 0 & 30 & 30 & 60 & 0 & 0 & 32 & 68 & 100 \\
\hline 20 & 0 & 0 & 34 & 26 & 60 & 0 & 0 & 32 & 68 & 100 \\
\hline 21 & 0 & 0 & 25 & 35 & 60 & 0 & 0 & 27 & 73 & 100 \\
\hline 22 & 0 & 0 & 28 & 32 & 60 & 0 & 0 & 43 & 57 & 100 \\
\hline 23 & 0 & 0 & 24 & 36 & 60 & 0 & 2 & 43 & 55 & 100 \\
\hline 24 & 0 & 0 & 35 & 25 & 60 & 0 & 0 & 65 & 35 & 100 \\
\hline 25 & 0 & 0 & 19 & 41 & 60 & 0 & 0 & 43 & 57 & 100 \\
\hline Total & 0 & 1 & $\begin{array}{r}71 \\
0\end{array}$ & $\begin{array}{r}78 \\
9\end{array}$ & $\begin{array}{l}15 \\
00\end{array}$ & 0 & 2 & $\begin{array}{r}83 \\
8\end{array}$ & $\begin{array}{l}16 \\
60\end{array}$ & $\begin{array}{r}250 \\
0\end{array}$ \\
\hline Avera & 0. & 0. & 28. & 31. & 60. & 0. & 0. & 33. & 66. & 100 \\
\hline ge & 0 & 0 & 4 & 6 & 0 & 0 & 1 & 5 & 4 & .0 \\
\hline
\end{tabular}

Table 6 Descriptive Analysis of Professionalism Variables

\begin{tabular}{|l|l|r|}
\hline Statistics & & \\
\hline TotalY & & 60 \\
\hline $\mathrm{N}$ & Valid & 0 \\
\hline & Missing & 88.13 \\
\hline Mean & & 0.629 \\
\hline Std. Error of Mean & & 87.5 \\
\hline Median & & 87 \\
\hline Mode & & 4,873 \\
\hline Std. Deviation & & 23,745 \\
\hline Variance & & 24 \\
\hline Range & & 75 \\
\hline Minimum & & 99 \\
\hline Maximum & & 5288 \\
\hline Sum & &
\end{tabular}

Histogram

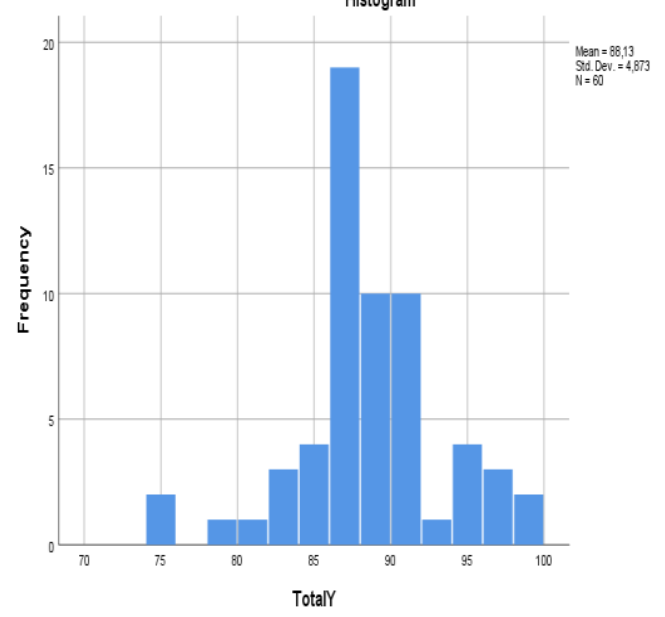

Figure 3 Distribution of Professionalism Variables

\subsection{Test Hypothesis: Teacher Professionalism to Work Culture}

Furthermore, testing the hypothesis of the effect of teacher professionalism on work culture. The results of hypothesis testing refer to Table 7 Anova. Based on Table 7, it is known that the deviation from linearity ( $\mathrm{sig}$ ) value is 248 , meaning that there is a relationship between work culture and teacher professionalism.

\begin{tabular}{|c|c|c|c|c|c|c|c|}
\hline & & & $\begin{array}{l}\text { Sum of } \\
\text { Squares } \\
\end{array}$ & df & $\begin{array}{l}\text { Mean } \\
\text { Square }\end{array}$ & $\mathrm{F}$ & Sig. \\
\hline \multirow{5}{*}{$\begin{array}{l}\text { Teacher } \\
\text { Professi } \\
\text { onalism } \\
\text { * Work } \\
\text { Culture }\end{array}$} & \multirow[t]{3}{*}{$\begin{array}{l}\text { Between } \\
\text { Groups }\end{array}$} & $\begin{array}{l}\text { (Combine } \\
\text { d) }\end{array}$ & 560,933 & 17 & 32,996 & 1,650 & .094 \\
\hline & & Linearity & 148,298 & 1 & 148,298 & 7,415 & .009 \\
\hline & & $\begin{array}{l}\text { Deviation } \\
\text { from } \\
\text { Linearity }\end{array}$ & 412,636 & 16 & 25,790 & 1,289 & .248 \\
\hline & \multicolumn{2}{|c|}{ Within Groups } & 840,000 & 42 & 20,000 & & \\
\hline & \multicolumn{2}{|l|}{ Total } & 1400,933 & 59 & & & \\
\hline
\end{tabular}

\subsection{Hypothesis Testing: Teacher Professionalism on Work Commitment}

Furthermore, testing the hypothesis of the effect of teacher professionalism on work commitment. The results of hypothesis testing refer to Table 8 Anova. Based on Table 8, it is known that the value of deviation from linearity (sig) is 284 , meaning that there is a relationship between work commitment and teacher professionalism.

Table 8 ANOVA

\begin{tabular}{|c|c|c|c|c|c|c|c|}
\hline & & & $\begin{array}{c}\text { Sum of } \\
\text { Square } \\
\text { s }\end{array}$ & df & $\begin{array}{c}\text { Mean } \\
\text { Square }\end{array}$ & $\mathrm{F}$ & Sig. \\
\hline \multirow{5}{*}{$\begin{array}{l}\text { Teacher } \\
\text { Professionalis } \\
\mathrm{m} * \text { Work } \\
\text { Commitment }\end{array}$} & \multirow{3}{*}{$\begin{array}{l}\text { Between } \\
\text { Groups }\end{array}$} & (Combined) & $\begin{array}{r}737,46 \\
9\end{array}$ & 15 & 49,165 & 3,26 & .001 \\
\hline & & Linearity & 476,15 & 1 & 476,15 & $\begin{array}{r}31,5 \\
78\end{array}$ & .000 \\
\hline & & $\begin{array}{l}\text { Deviation } \\
\text { from } \\
\text { Linearity }\end{array}$ & $\begin{array}{r}261,31 \\
4\end{array}$ & 14 & 18,665 & $\begin{array}{r}1,23 \\
8\end{array}$ & .284 \\
\hline & \multicolumn{2}{|c|}{ Within Groups } & $\begin{array}{r}663,46 \\
4 \\
\end{array}$ & 44 & 15,079 & & \\
\hline & \multicolumn{2}{|l|}{ Total } & $\begin{array}{r}1400,9 \\
33\end{array}$ & 59 & & & \\
\hline
\end{tabular}

\subsection{Hypothesis Testing: The Effect of Work Culture and Teacher Commitment to Professionalism}

Based on the results of the regression test (Table 9), the regression equation constant value (a) is 9.746; the coefficient value of the independent variable (b1) is 0.270 ; and the value (b2) of 0,596 . Then the regression equation is obtained:

$\mathrm{Y}=9.746+0.270 \mathrm{X} 1+0.596 \mathrm{X} 2$

This means that work culture and commitment have a significant effect on teacher professionalism. To find out the truth of hypothesis testing, a simultaneous test was carried out using the $\mathrm{F}$ test to determine the effect of work culture variables and teacher commitment to professionalism. The test criteria are: (a) if the probability value (significant) $<0.005$, then Ho is rejected; and (b) if the probability value ( significant) $>0.005$, then Ho is accepted. Then for the 
F test, the test criteria are: Ha is accepted if Fcount > Ftable. Hypothesis testing by referring to Table 9.

Table 9 Results of X1 and X2 Regression Analysis on Y

\begin{tabular}{|l|l|l|l|l|l|l|}
\hline \multicolumn{7}{|c|}{ ANOVAa } \\
\hline \multicolumn{2}{|c|}{} & $\begin{array}{c}\text { Sum of } \\
\text { Squares }\end{array}$ & Df & $\begin{array}{c}\text { Mean } \\
\text { Square }\end{array}$ & F & Sig. \\
\hline \multirow{2}{*}{1} & Regression & 564,641 & 2 & 282,320 & 19,242 & $.000 \mathrm{~b}$ \\
\cline { 2 - 8 } & Residual & 836,292 & 57 & 14,672 & & \\
\cline { 2 - 8 } & Total & 1400,933 & 59 & & & \\
\hline
\end{tabular}

a. Dependent Variable: Professionalism

b. Predictors: (Constant), Work_Commitment, Work_Culture

Based on Table 9, it is known that the Fcount value is 19.242 with sig. amounting to 0,000 . Meanwhile, the critical value of the $\mathrm{F}$ table distribution is $3,160(\mathrm{~F}$ table $=\mathrm{F}(\mathrm{k} ; \mathrm{nk})=\mathrm{F}(2 ; 60-2)=\mathrm{F}(2 ; 58)=$ $3,160)$.

\section{Hypothesis Testing Guidelines:}

Fcount $>$ Ftable $=$ Ha, accepted

Fcount $<$ Ftable $=$ Ha, rejected

Based on the guidelines for testing the hypothesis, with a significant level of 0.05 , it is known that the value of Fcount $=19.242$ while Ftable $=3.160$, then Fcount $>$ Ftable which means that Ha is accepted. Thus, the hypothesis in this study states that there is a significant influence on work culture and work commitment to professionalism. To find out how much influence the independent variable has on the dependent variable simultaneously, it can be seen in Table 10. Based on Table 10, the Rsquare value is 0.403. It is concluded that the contribution of work culture and work commitment to professionalism is $40.3 \%$ and the remaining $59.70 \%$ is influenced by other factors which are not examined in this study.

Table 10 Model Summary

Table 10 Model Summary
\begin{tabular}{|c|c|c|c|c|}
\hline Model & R & R Square & $\begin{array}{c}\text { Adjusted R } \\
\text { Square }\end{array}$ & $\begin{array}{c}\text { Std. Error of the } \\
\text { Estimate }\end{array}$ \\
\hline 1 &, $635 \mathrm{a}$ &, 403 &, 382 & 3,830 \\
\hline
\end{tabular}

a. Predictors: (Constant), Work_Commitment, Work_Culture

The results of research conducted by Suwandi [2] concluded that there was an influence of school principal leadership, work culture, and work commitment to teacher professionalism. This shows that a good work culture can affect the professionalism of existing teachers. The term "professionalism" means a characteristic that is displayed in an act, there is a commitment to improve skills or abilities in carrying out work in accordance with the profession [10]. Professionalism is a term that refers to a mental attitude in the form of commitment of members of a profession to always create and improve their professional quality [11], [12].

Work culture is the values that become one's habits in determining the quality of a person at work [13], [14]. Every school has a work culture that affects organizational aspects and the behavior of its members individually and in groups [15], [16]. The current reality is that the existence of professional teachers is still far from what they aspire to. There are still many low-quality schools that give a signal that professional teachers are just a discourse that has not been realized equally. This raises a concern that does not only come from academics, but lay people also comment on the existing education and teaching staff. In this regard, educational observers argue that teachers are a key factor of various factors that can affect student achievement and learning outcomes [17], [18].

Professional teachers are teachers who are able to play a role in educating, teaching, guiding [19], [20], directing, training, assessing, and evaluating students in early childhood education [21], [22], formal education, basic education., and secondary education using skills, proficiency [23], [24], and skills that meet certain quality standards or norms [25], [26]. Given the heavy duties and responsibilities of a teacher, either as a teacher for students or as personnel, members or individuals in the school who are required to be able to help and empower schools to become better, develop and achieve. So the commitment of teachers in an organization in schools is very important in realizing quality education [27], [28].

\section{CONCLUSION}

Based on the results of the study, it was concluded that there was an influence of work culture and work commitment on teacher professionalism. If someone has a good work culture and is highly committed to realizing common goals, then he will become a professional person and have high professionalism as well.

\section{REFERENCES}

[1] N. Fattah, "Landasan Manajemen Pendidikan". Bandung: Remaja Rosdakarya, 2008.

[2] Suwandi. 2016. Pengaruh Kepemimpinan Kepala Sekolah, Budaya Kerja dan Komitmen Kerja terhadap Profesionalisme Guru. Jurnal Manajemen Mutu Pendidikan.

[3] J. Greenberg, and R. A. Baron, "Behavior in Organizations: Understanding and Managing the Human Side of Work". New Jersey: PrenticeHall, Inc, 2003.

[4] Sugiyono, "Metode Penelitian Pendidikan (Pendekatan Kuantitatif, Kualitatif, dan R\&D". Alfabeta: Bandung, 2011.

[5] Sugiyono, "Metode Penelitian Kombinasi (Mix Methods)". Bandung: Alfabeta, 2015.

[6] Silalahi, "Metode Penelitian Sosial". Bandung: PT Refika Aditama, 2009.

[7] Sugiyono, "Metode Penelitian Kuantitatif, Kualitatif dan R\&D". Bandung: PT Alfabeta, 2016.

[8] S. Arikunto, "Prosedur Penelitian: Suatu Pendekatan Praktik". Jakarta: Rineka Cipta, 2006.

[9] S. Arikunto, "Prosedur Penelitian: Suatu Pendekatan Praktik". Jakarta: Rineka Cipta, 2013.

[10] B. Alma, "Guru Profesional Menguasai Metode dan Terampil Mengajar”. Bandung: Alfabeta, 2008. 
[11] Suyanto, "Menjadi Guru Profesional". Jakarta: Erlangga, 2013.

[12] F. D. Pratiwi, I. Gunawan, B. A. Mahardika, C. N. Cahyaning, P. U. Amaliah, M. A. Adha, and S. P. Lestari, "Principal's Role in Thematic Learning Supervision That Works in Elementary School". In 6th International Conference on Education and Technology (ICET 2020) (pp. 176-181), Atlantis Press, 2020.

[13] D. E. Kusumaningrum, R. B. Sumarsono, and I. Gunawan, "Pengaruh Kepemimpinan Pembelajaran, Kepemimpinan Perubahan, Kepemimpinan Spiritual, Budaya Sekolah, dan Etika Profesi terhadap Kinerja Mengajar Guru". JMSP (Jurnal Manajemen dan Supervisi Pendidikan), Vol. 4, No. 3, p. 198-219, 2020.

[14] Juharyanto, A. Nurabadi, and I. Gunawan, "Debat Moral Sebagai Upaya Meningkatkan Integritas Kepala Sekolah". JAMP: Jurnal Administrasi dan Manajemen Pendidikan, Vol. 3, No. 3, p. 272-282, 2020.

[15] B. A. Pambudi, and I. Gunawan, "The Effect of Learning Leadership and Academic Supervision on Teacher Teaching Skills in the Covid-19 Pandemic". In 6th International Conference on Education and Technology (ICET 2020) (pp. 1-5), Atlantis Press, 2020.

[16] E. M. Budiarti, I. Gunawan, and B. A. Pambudi, "The Effect of Spiritual Leadership and Academic Supervision on Teacher Performance". In 6th International Conference on Education and Technology (ICET 2020) (pp. 157-161), Atlantis Press, 2020.

[17] S. Taftania, A. Kusna, B. A. Mahardika, D. R. Nugraheni, D. Eriyani, N. O. Yulindasari, ... \& I. Gunawan, "Implementation of Total Quality Management through the Leadership of Schools in Efforts to Improve Teacher Creativity: A Conceptual Paper". In 1st International Conference on Information Technology and Education (ICITE 2020) (pp. 501-505), Atlantis Press, 2020.

[18] N. N. Sukawati, I. Gunawan, A. G. Prayoga, and A. D. Wardani, "Teacher Personality, Interpersonal Relationships, Performance, and Professionalism in the Learning Process: A Qualitative Study". In 6th International Conference on Education and Technology (ICET 2020) (pp. 250-254), Atlantis Press, 2020.

[19] D. Prestiadi, I. Gunawan, and R. B. Sumarsono, "Role of Transformational Leadership in Education 4.0". In 6th International Conference on Education and Technology (ICET 2020) (pp. 120-124), Atlantis Press, 2020.

[20] A. N. Miroj, B. R. Saputra, and I. Gunawan, "Principal Learning Leadership Tips Managing
Learning in Schools". In 6th International Conference on Education and Technology (ICET 2020) (pp. 85-88), Atlantis Press, 2020.

[21] N. Y. Rizky, I. Gunawan, and A. D. Wardani, "Compensation and Performance of Educators in Schools: A Qualitative Study". In 6th International Conference on Education and Technology (ICET 2020) (pp. 259-263), Atlantis Press, 2020.

[22] N. O. Yulindasari, A. Kusna, B. A. Mahardika, D. R. Nugraheni, D. Eriyani, S. Taftania, ... \& I. Gunawan, "Principal's Visionary Leadership in the Framework of School Change Process". In 1st International Conference on Information Technology and Education (ICITE 2020) (pp. 477-483), Atlantis Press, 2020.

[23] A. Nurabadi, I. Bafadal, E. T. Priyatni, and I. Gunawan, "Analysis of the Availability of School Facilities and Infrastructure as an Effort to Accelerate School Quality Improvement". In 6th International Conference on Education and Technology (ICET 2020) (pp. 89-92), Atlantis Press, 2020.

[24] A. Prastiawan, I. Gunawan, A. P. Putra, D. A. Dewantoro, P. S. Cholifah, N. L. S. Nuraini, ... \& E. Surahman, "School Leadership Skills in Educational Institutions". In 6th International Conference on Education and Technology (ICET 2020) (pp. 438-441), Atlantis Press, 2020.

[25] N. W. N. Setya, I. Gunawan, D. E. Kusumaningrum, R. B. Sumarsono, A. Nurabadi, L. K. Hui, ... \& F. B. Santoso, "Development of Student Leadership Variables Instruments: Validity and Reliability Analysis". In 1st International Conference on Information Technology and Education (ICITE 2020) (pp. 541-545), Atlantis Press, 2020.

[26] A. N. Faizah, I. Gunawan, I. Bafadal, and A. Timan, "The Relationship between Learning Leadership and Teacher Performance: A Correlation Analysis". In 1st International Conference on Information Technology and Education (ICITE 2020) (pp. 599-602), Atlantis Press, 2020.

[27] I. Bafadal, I. Gunawan, and A. Nurabadi, "Leadership in Excellent School: A Qualitative Study". In 1st International Conference on Information Technology and Education (ICITE 2020) (pp. 63-66), Atlantis Press, 2020.

[28] I. Gunawan, F. D. Pratiwi, N. W. N. Setya, A. F. Putri, N. N. Sukawati, F. B. Santoso, ... \& N. Hidayati, "Measurement of Vocational High School Teachers Professionalism". In 1st International Conference on Information Technology and Education (ICITE 2020) (pp. 6772), Atlantis Press, 2020. 